一東京都一

\title{
スナックバー “ブスケ”の照明
}
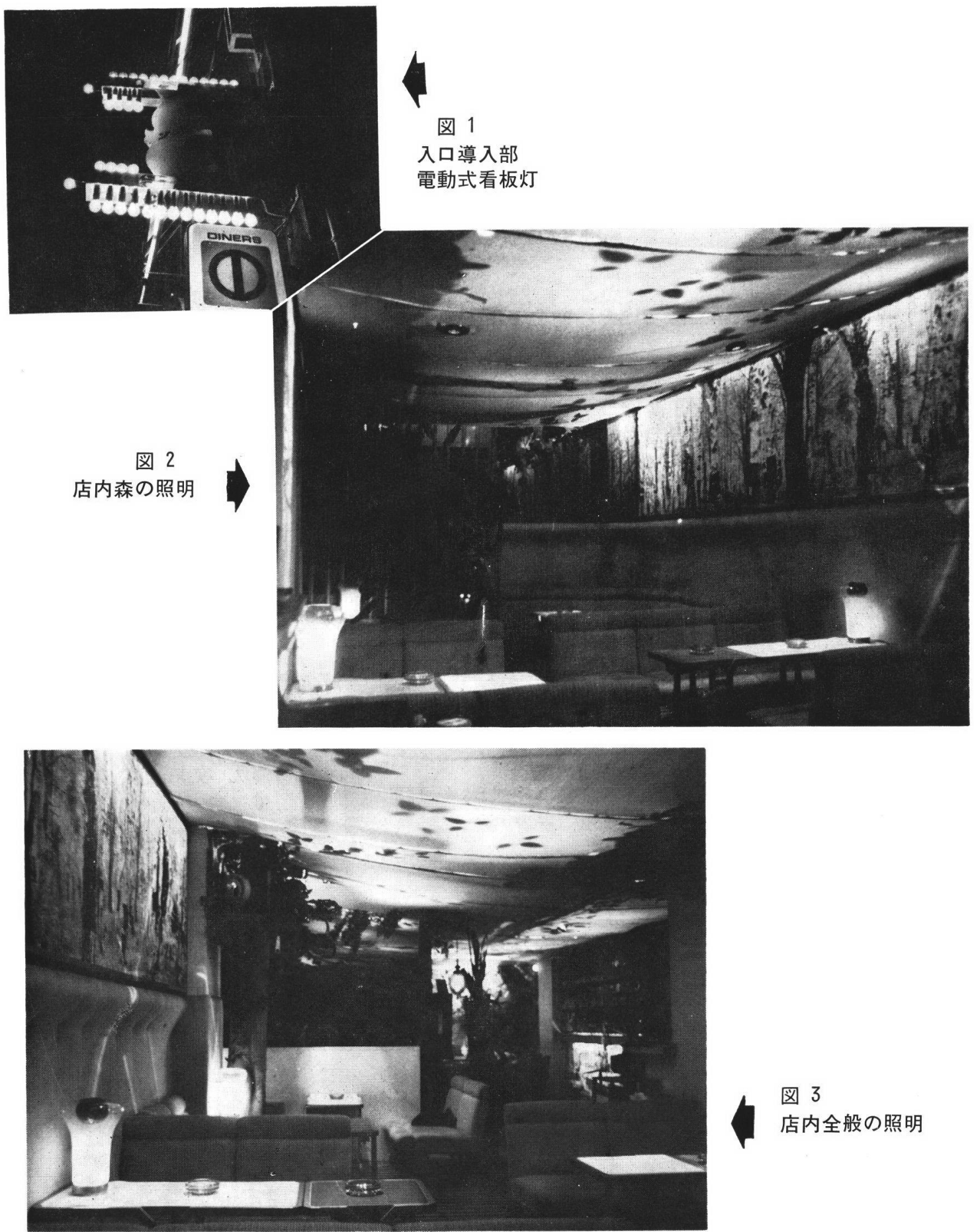

图 3 店内全般の照明 
昭和 46 年 6 月, 地下鉄六本木 駅前地下に森のイメージを表現 したインテリアデザインと，そ の照明効果をもつスナックバー “ブスケ”がオープンした.

“ブスケ”はフランス語で森 を意味し, 店内天井面は, キャ ンバス布張りにデザインされ, あたか子森を思わせる写真がイ ンテリアにレイアウトされ, 森 のイメージを演出する照明効果 は，エレクトーンの快い音色と ともに, ファンタジックな森の ふんい気をか子し出している.

\section{照明の概要と設備}

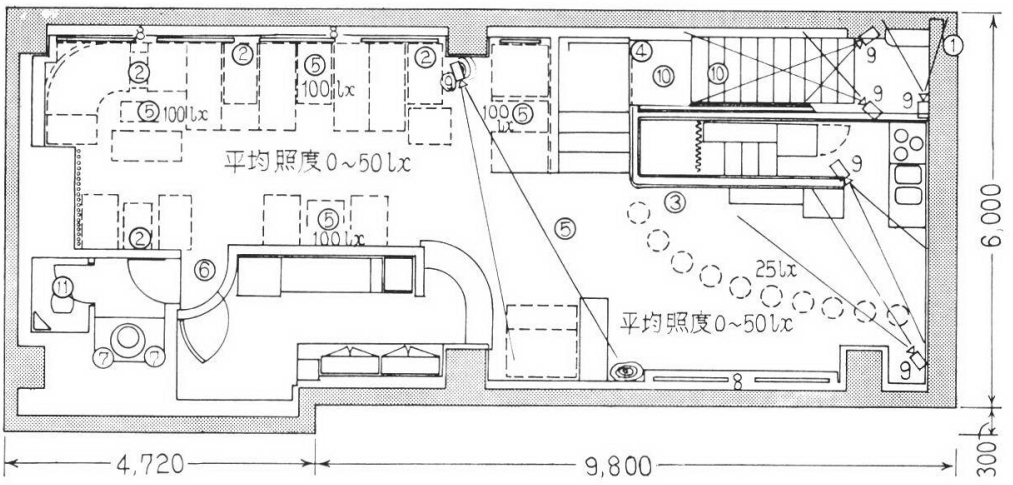

\section{図 4 店内照明器具配置ならびに照度分布図}

図に配置された器具のほかに, 全般照明として天井スラブ面に $40 \mathrm{~W}$ じから゙け器具 18 灯が配置されている(調光器付き)。 また，店内キャンバス布張り天井裏全般に わたり葉形の大型モビールを 17 台設置している.

$\begin{array}{llll}\text { (1) } 20 \mathrm{~W} 50 \phi \text { クリヤーランプ36灯用看板灯 } 1 \text { 台 } & \text { (7) } 20 \mathrm{~W} \text { 洋風ブラケット }\end{array}$

(2) $40 \mathrm{~W}$ カラーランプきのこ形テーブルスタンド 4 台 (8) FL $-40 \mathrm{~W} \times 1$ じからけ器具(赤から紫ま

(3) 40 Wカラーランプペンダントー 1 台价 7 色カラーフィルタ使用)

(4) 40 Wカラーランプペダン

1 台 (2゙の7 色カラーフィルタ使用)
1 台 $150 \mathrm{~W} 3$ 色電動式プロジェクタ

スナックバーの持つべき特質性から，客の多様な要求 にこたえられるよう，個性的な導入部と内部空間を創造 することに方針を置さ, 自然が生み出す情緒を照明によ って流動的なタッチで店内そつつむなど，店内全般の照 明デザイン思想を，森が描くコントラストを主に設計を 行なっている.

遠目からも，その所在を明らかに表示するエキサイト ライティング効果を活用し, $20 \mathrm{~W} 50 \phi$ 透明白熱電球 36 灯を取り付けた屋外メイン看板灯をはじめ，店舗入口の 階段部に立体的な広がりと壁面照明を兼ね，150 W 3 色 電動式プロジェクタにより，色彩と動きの変化をもたせ 誘導効果をねらっている(図 1 参照).

地下店内 (面積 $87 \mathrm{~m}^{2}$ ) 天井面全域が，キャンバス布 張りにデザインされ，天井裏スラブは $40 \mathrm{~W}$ じからけ器 具 18 灯が $0 \sim 50 \mathrm{~lx}$ まで調光器によって明暗の変化を天 井布面につけている. また天井裏より要所要所につられ た葉形の大型モビールは, 空調の微風をもって, 天井布 面に自由なやわらかい動きで，風にゆれ動く木の葉のシ ルエットを描き出している.

壁面の木立の大胆な布製写真には, 木立の生い茂り と, その木々の間からもれる太陽光とを創造するため, 写真内側のけい光灯に, 赤から紫までの 7 色のカラーフ イルタを設置することにより店内全般のイメージは, 昼 と夜の姿をもつ森のふんい気を十分に発揮している（図 2 参照).

各客席テーブル面には，照射面積自在のレンズ付き白 熱灯 $60 \mathrm{~W}$ 小型スポットで，局部的に高照度 (100 lx) の はなやかさを演出し，また各顧客にドラマティックな手 法で神秘性を盛り上げる意味から， $40 \mathrm{~W}$ カラーランプ

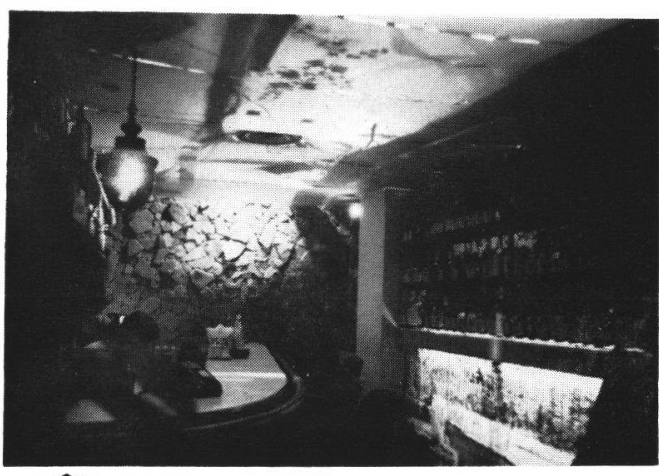

図 5 店内カウンターまわりの照明

のきのこ形テーブルスタンドを設置するなど，その一j 店内にリズミカルならんい気もかもし出すように, 壁面 および洋酒だなに $150 \mathrm{~W}$ 電動式プロジェクタでカラーを 投げかけ，そのフレキシビリティにとんだ照明効果は小 さな森の祭り場を感じさせる。

店内平均照度 $\quad 0 \sim 50 \mathrm{~lx}$ (調光器付き)

客席テーブル面円形スポット投影照度

$100 \sim 1501 \mathrm{x}$

施 主 䄱開堂

設計監理台原建築設計事務所

照明設計東宮照明設計事務所

秼協電社

照明器具製作 ヤマギワ電気㭌

（資料提供 東宮照明設計事務所） 専門会員 東宮 伝 正会員神林祐治 


\section{- \\ -

一新 潟 県一

\section{苗場国際スキー場の照明}
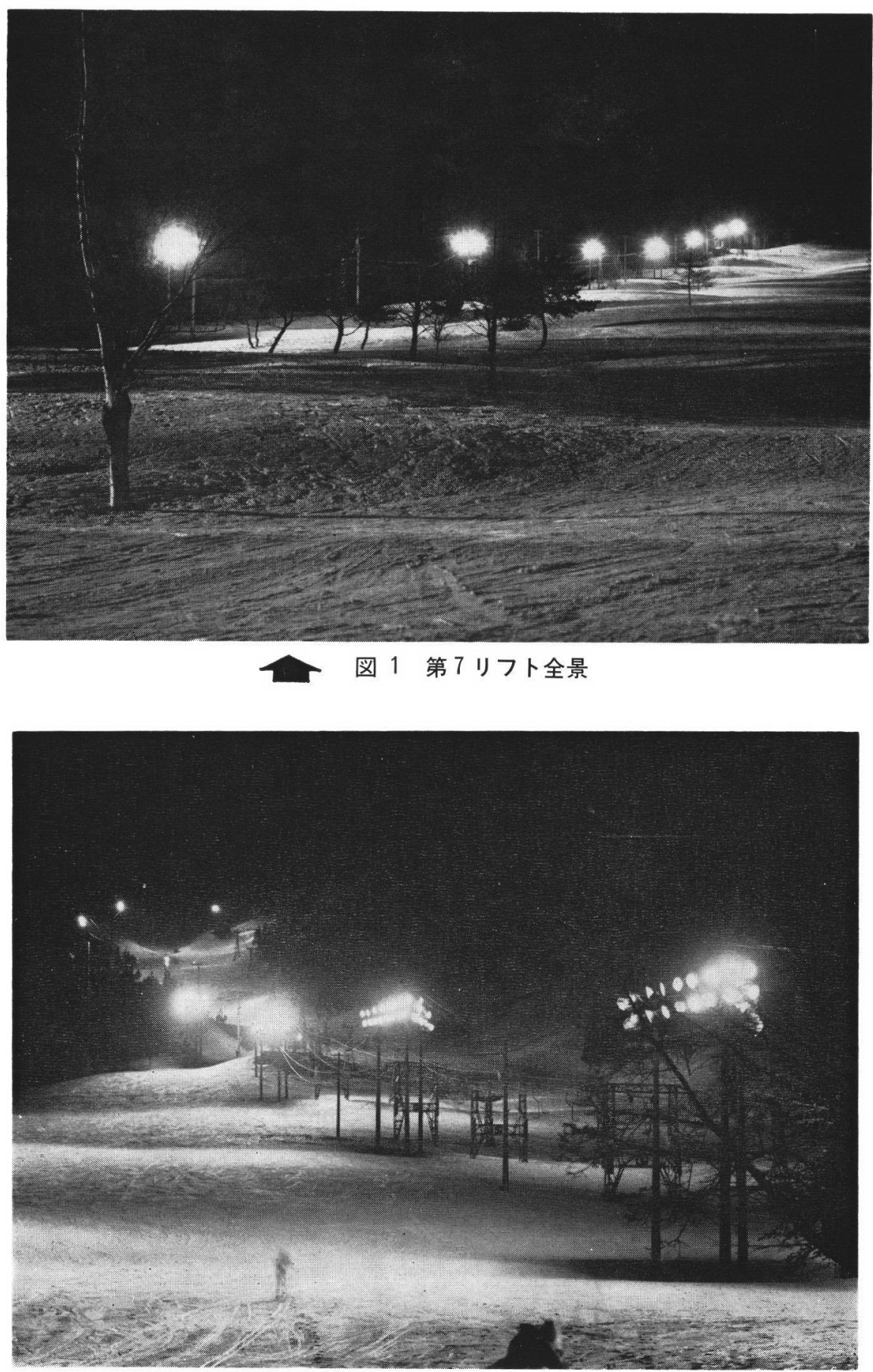

1 図 2 第4リフト全景 


\section{概} 要

苗場国際スキー場は， 396 万 $\mathrm{m}^{2}$ 亿及ぶ広大なゲレン デ，スラロームコースなど変化に富んでおり，スキーヤ のメッカに店っている.

このほど，第 4 リフ C 線 $700 \mathrm{~m}$ (简山側) と第 7 リ フト $740 \mathrm{~m}$ (浅具側) の 2 本のリフトが新設されたのを 機会に, 新しく $1 \mathrm{~kW}$ 水銀灯投光器 143 台が增設され, 従米の $1 \mathrm{~kW}$ 水銀灯投光器 167 台と合わせ, 合計 310 台 の大規模な夜間照明設備となっている.

\section{1. 第 7 リフトの照明設備}

図 1 に全景を示す．740 $\mathrm{m}$ に及ぶリフトに沿って，そ の右側に 16 本の送電柱孞 $50 \mathrm{~m}$ 間隔で設子られ，その半 数の 8 本が照明塔である. 各照明塔は図 3 に示すよら に, $1 \mathrm{~kW}$ 水銀灯投光器 $\mathrm{HJ}-10028$ が 10 台 (HF 1000A $\times$ 7 ， H $1000 \mathrm{~A} \times 3$ ) ずつ合計 80 台配置されている. ゲレン

\section{2. 第 4 リフトの照明設備}

図 2 亿全景を示す，第 4 リフトのA，B線 $(400 \mathrm{~m})$ と並行してさらに山頂へ $300 \mathrm{~m}$ 延びたC線 $(700 \mathrm{~m})$ の 增設によって，同りフトを中心に左右のゲレンデ（C線 卜部は片側コース）を広範四に照明している.

新設のC線上部約 $300 \mathrm{~m}$ のダレンデには $1 \mathrm{~kW}$ 水銀灯 投光器 HT-10028が 32 台設子られている.この部分の 照明塔は第 7 リマと同じタイプで 10 灯用が 3 基， 2 灯用が 1 基没怙られている。 また A， B線りフト終点か ら谷侧の左右ゲレンデ照明用として， 32 灯用が 3 基， 24 灯用が 1 基， 2 灯用が 1 基設讨られ，全体では $153 \frac{1}{1}$ の $1 \mathrm{~kW}$ 水銀灯投光器が使用されている.

図 5 亿照明塔の配置㧍よび照度分作を示す.照明され ている範明は，リフト中間点 $(\mathrm{A}, \mathrm{B}$ 線の終点)から谷側 は左右ダレンデとも幅 $40 \sim 60 \mathrm{~m}, \mathrm{C}$ 線上部コースは幅 15 $\sim 20 \mathrm{~m}$ で，照度は設借当初平均 30〜60 lx を得ている.

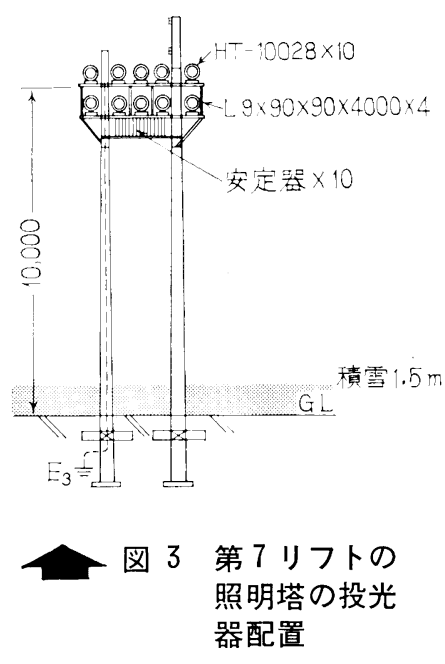

デのコース幅は 30〜60 m である が, 図 4 の照度分布のよらに没備 当初に捻いて 20〜60 lx の照度を 得ている.

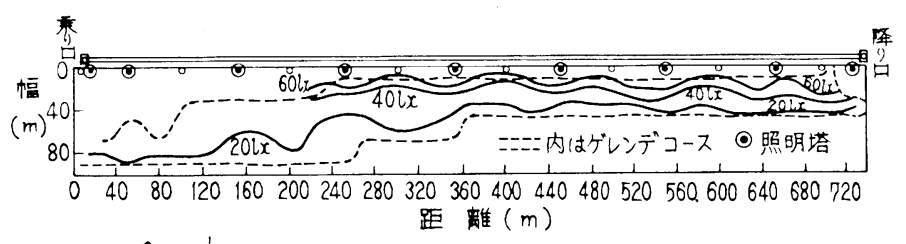

図 4 第 7 リフトの照明塔の配置および 照度分布図

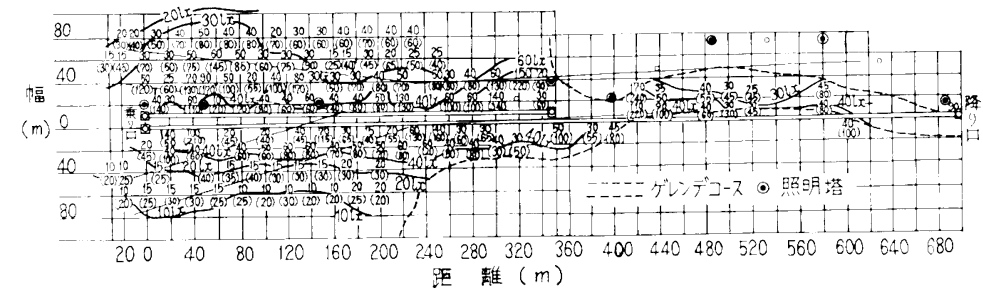

図 5 第 4 リフトの照明塔の配置および 照度分布図

\begin{tabular}{|c|c|}
\hline 主: & 国土計画踭 \\
\hline 没 & 国土計画㧣新鼬支店施設課 \\
\hline 霆気工事 & 侏関電気 \\
\hline
\end{tabular}

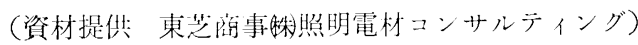

正会員 家老正 俊 


\section{-

一別 府 市一

\section{身障者住宅 太陽の家の照明}

図 1

太陽の家

(TESTEM)

の正面外観
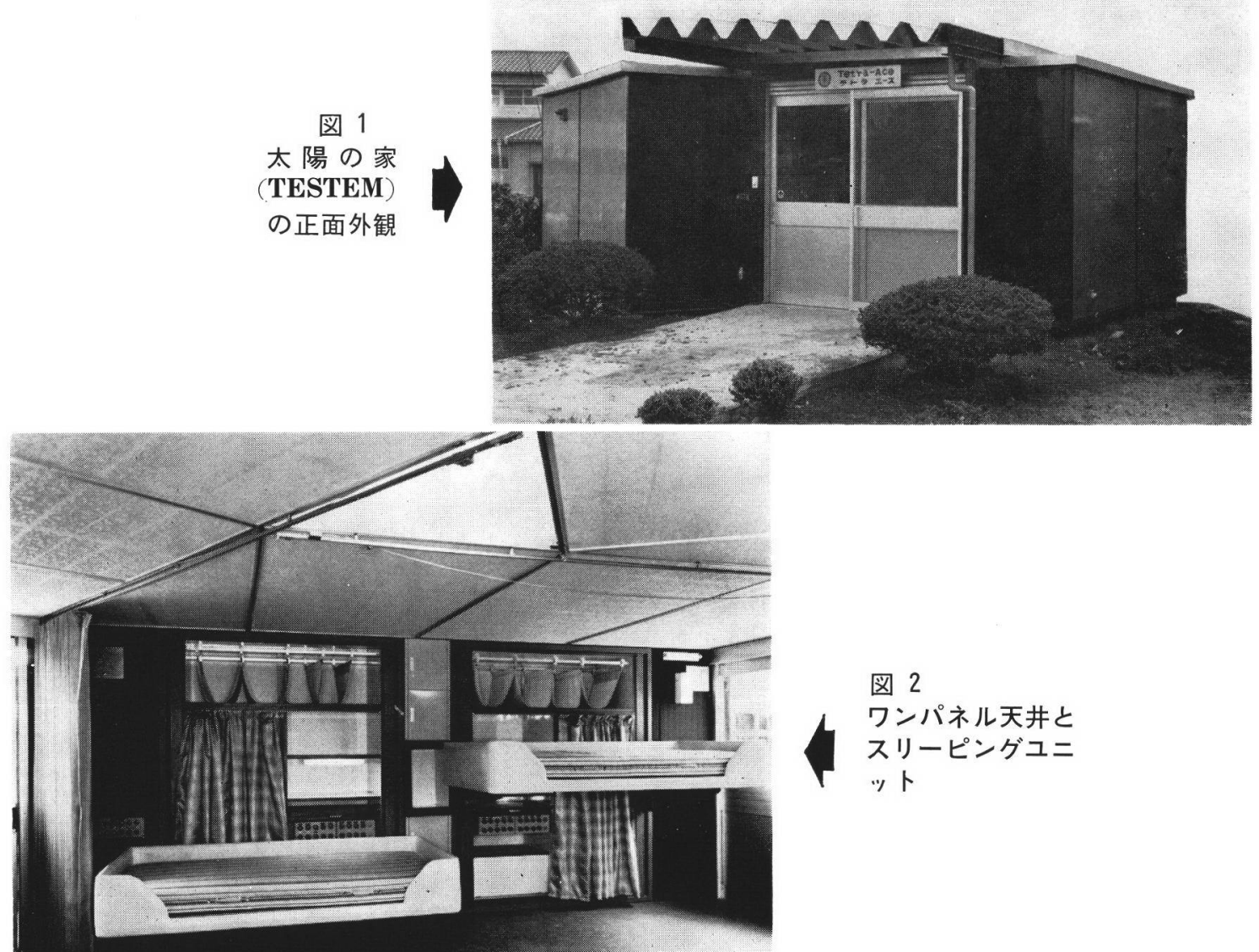

図 2

$4 \begin{aligned} & \text { ワンパネル天井と } \\ & \text { スリーピングユニ }\end{aligned}$

図 3

キッチン

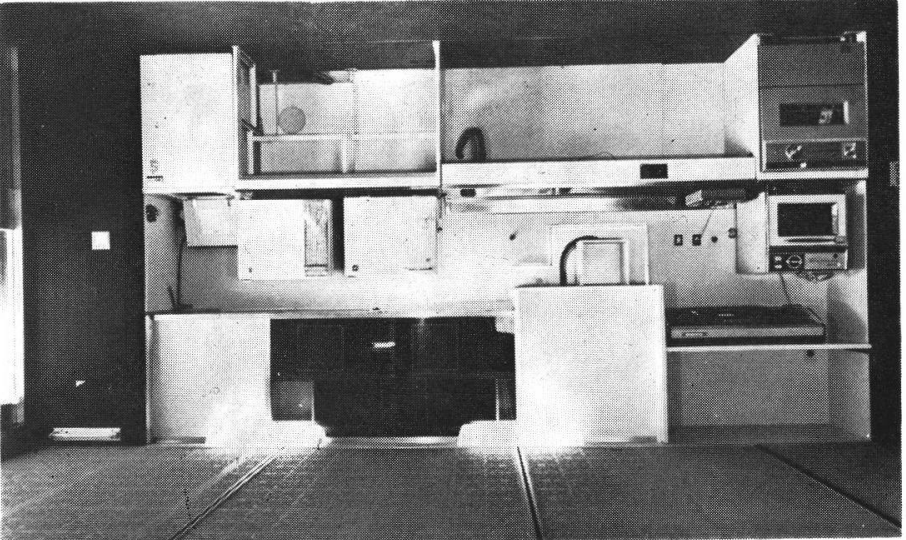


この住宅は身障者用の住宅として，別府市の社会福祉 法人「太陽の家」に建設されたプレハブ式平家建て床面 積 $47 \mathrm{~m}^{2}$ (14 坪) の全自動化モデル住宅である. TEST. $\mathrm{EM}$ の名称は同住宅システムの創案者, 池辺教授の持論 「住宅とは，環境(Environment)，空間(Space)，道具 (Tool), エネルギー (Energy), 人間(Man) と五つの 要素がシステム的に組み合わされたもの，すなわち ESTEM である」との理念に基づき，それに「太陽の家」 の頭文字索つけたものである。この家に居住する人

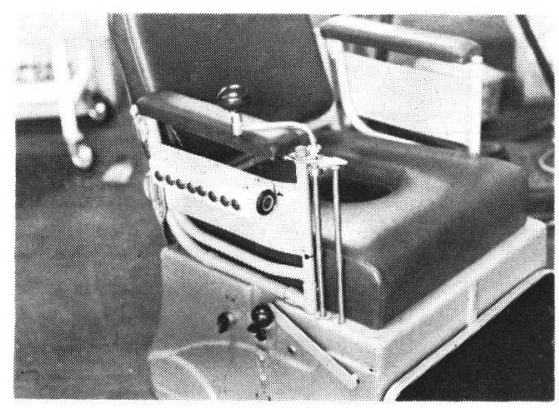

図 4 身障者用車いす

(コントロールぼたんと)

は，身体の自由がきかないため車いすに乗る重度の身障 者である，そのため自力で日常生活がでさるよら住宅内 の諸設備は, ロボット工学の森教授の指導で, ドアの開 閉，洗面所やベッドなど，あらゆる設備の操作は自動化 され，超音波の遠隔操作も可能となっている.

さらに住宅の工業化の効率を高めるため, 台形の基本 ユニット 3 個を組み合わせて, 柱のない変形六角形の室 内空間が形成され，それぞれの面に，サニタリーユニッ ト，スリーピングニニット，キッチンユニットの三つの 設備ユニットが取り付けられている。

\section{照 明 設 備}

新しい住宅の設備機能として，基本設備は照明，給湯 冷暖房，換気，非常電源，防災通信などが完備されてい る. 電気設備の容量は単相 3 線 $200 \mathrm{~V}, 150 \mathrm{~A}$ となって いる.

照明設備は, 最新の複合天井システム「ワンパネル」 により，室の中央部に主照明が設けられている，透明プ リズムパネル内に $20 \mathrm{~W}$ けい光灯 6 灯と $150 \mathrm{~W}$ シールド ビーム電球 3 灯を内蔵し, ランプ全点灯時には, 室の中 心付近で照度 $5001 \mathrm{x}$ となり，室に中心感をつくり，光色 もアトホームなやわらかい光となった. 三つの設備ユニ ットも専用の照明で $100 \sim 3001 \mathrm{x}$ の照度が保たれている.

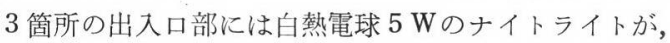
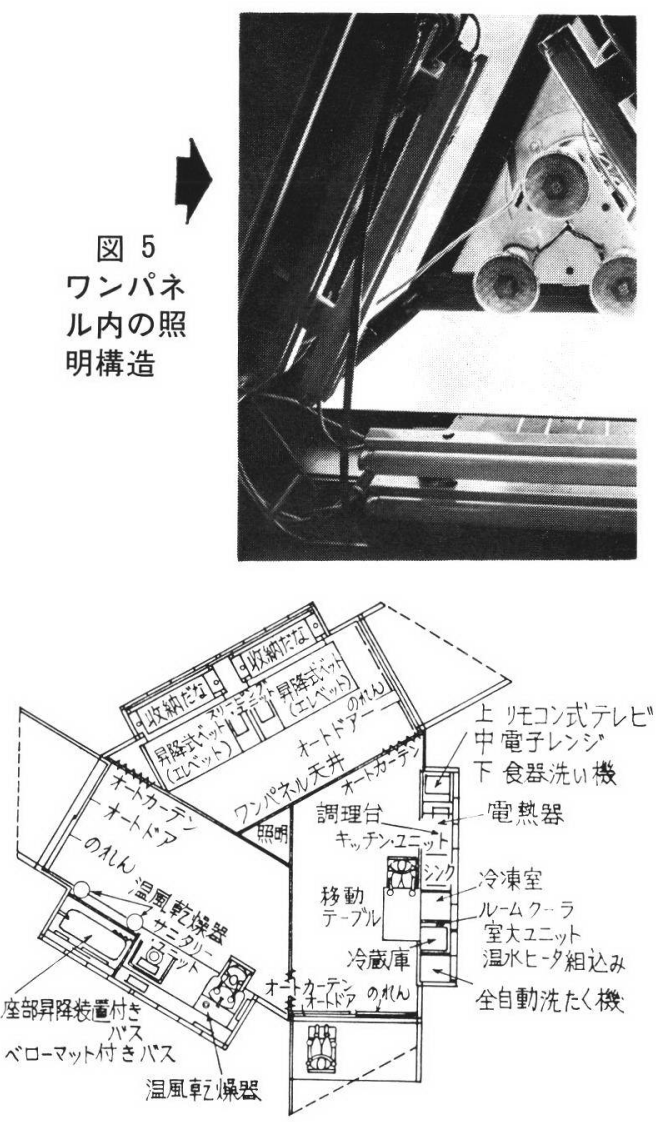

図 6 身障者住宅の平面図

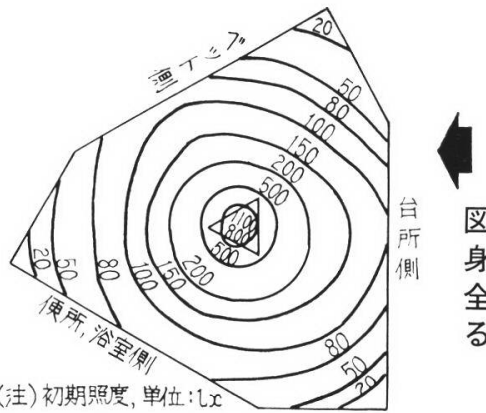

図 7

身障者住宅の 全般照明によ る照度分布

また，防㷋用非常灯として $10 \mathrm{~W}$ けい光灯器具が取り付 けられポーチには，EE スイッチと連結されたけい光 灯ウォールライトがついている.

\begin{tabular}{|c|c|}
\hline 主. & 社会福祉法人「太陽の家」 \\
\hline 施 & ナショナル住宅建材 \\
\hline 設工事 & $\begin{array}{l}\text { 佐伯建設(秼)，富士重工(秼) } \\
\text { 新倉電業秼) }\end{array}$ \\
\hline
\end{tabular}

（資料提供 松下電工踭照明事業部L A B ) 専門会員 門永 鉄雄

第 55 巻 第 10 号照 明 学 会 雑 誌 昭和 46 年




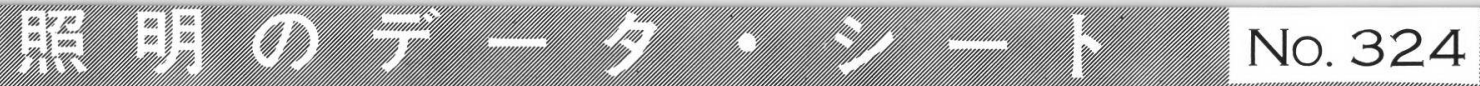

一昭島 市一

\section{昭和ゴルフ練習所の照明}

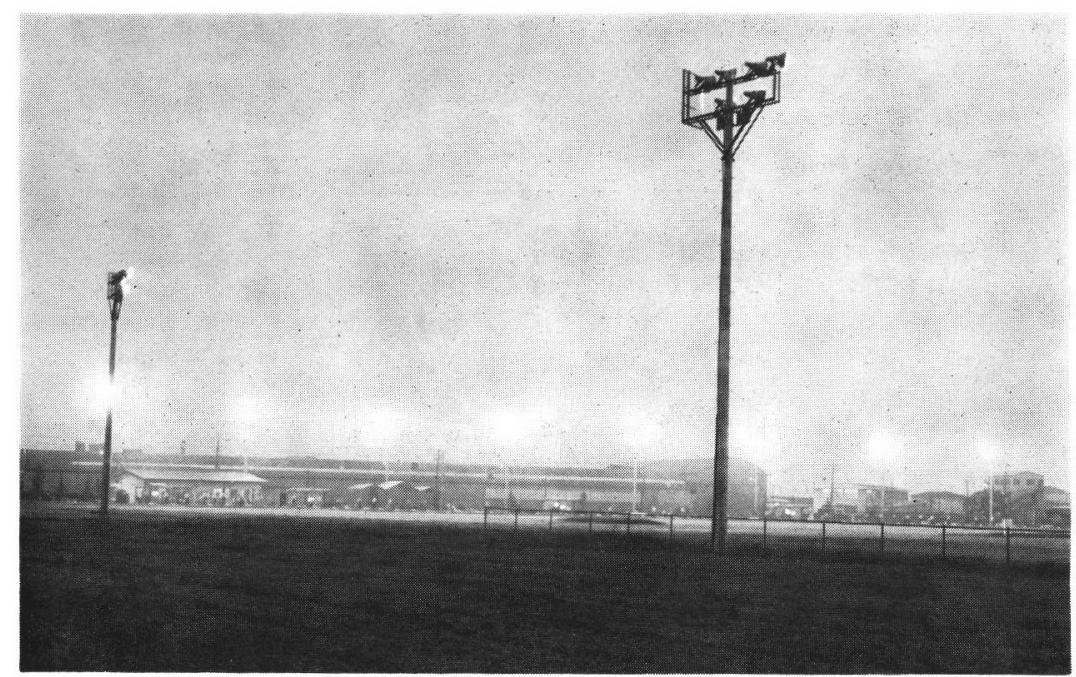

1 図 1 練習所夜間の全景

図 3

打席より見た フェアーウェ イの全景
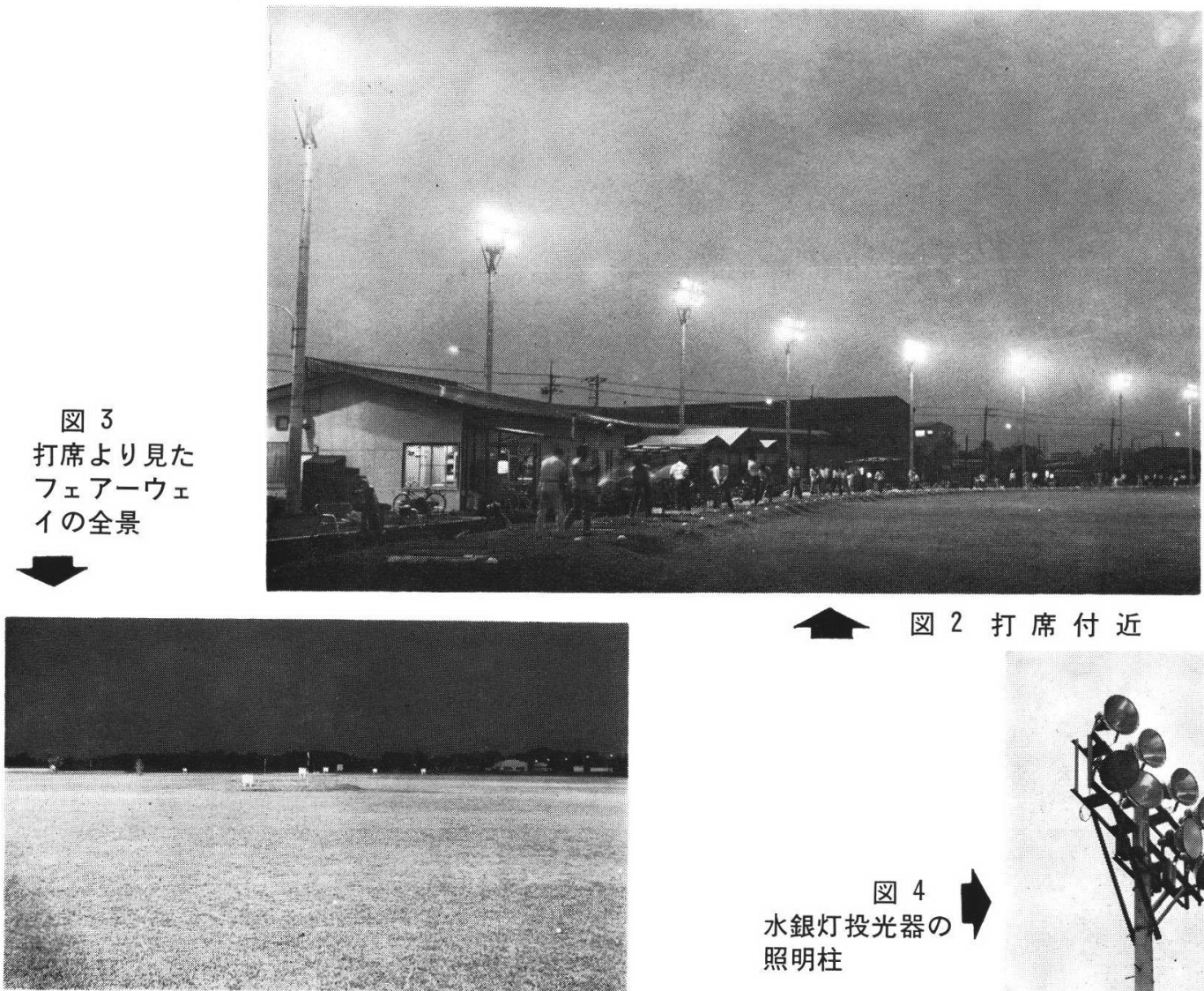

2 図2打席付近

Vol. 55 No. 10 図 4
水銀灯投光器の
照明柱

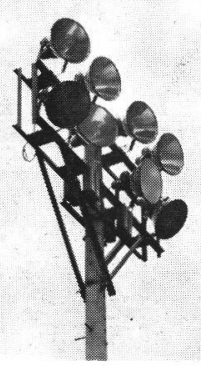


概

要

ゴルフブームの風潮を反映し，ゴルフの大菜化といら 要望にこたえて，東京都昭島市にある昭和パブリックコ

一スの隣㩲地に㕕大な昭和ゴルフ練翼所がある。この練 習所にゴルファー待望のナイター設備が，今年の 7 月下 旬に完成した。

本ゴルフ練習所は 70 打席 300 ヤード打ち放しで，特 に打席には屋根が無く，尧際にコースでブレーを行なら と同じような感じを出しているのが特長とされている.

図 1 亿夜間の全景，図 2 亿打席付近，図 3 に打席よ り見たフェアーウェイの全景を示す。な脑図 4 には水 銀灯投光器の照明柱を示与。

\section{照 明 設 備}

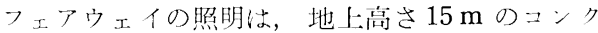
リ一柱 12 基を使用し，打席後方的 $10 \mathrm{~m}$ の位㫛に 8 基 ( $\mathrm{A}$ 柱)，两側に 2 基（B 柱）ナ゙つ配置されて いる. 各灯柱には $1,000 \mathrm{~W}$ 水銀ランブ用投光器（遠 距離形） 6 基が取り付忊られている.

照射方向はフェアウェイの中心部を重点的にねら っているのは，ボールの回收を簡素化するため，打 席の形状を医滦円泒形に設計されているためであ る。なお，照射範畔として200ヤード以内とした。

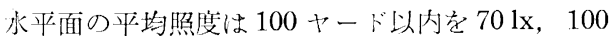
〜200ナードを $201 \mathrm{x}$ とした。図 5 に水平面照度分

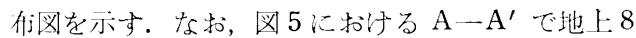
$\mathrm{m}$ の鉛消面照度は図6 亿示す。

打席の照明は演色性に重点を抢きA柱より 1,000 W けい光水銀ランプを使用した投光器で, 各柱より 2 台ずつ合計 16 台で平均 $180 \mathrm{~lx}$ 是得ている.

表 1 に各柱に扣外る投光器の分訳を示与.

施主师和興発侏

所在 地

設管理昭和飛行機工業秼総務㰾施設課

施工二三鉱举業侏

照明器源\}岩崎電気(

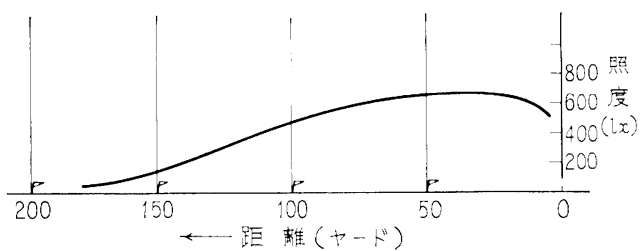

図 5 水平面照度分布図

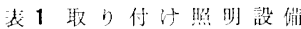

\begin{tabular}{|c|c|c|c|c|c|}
\hline & 投光器具形式 & ランプ形式 & 数 样 & ポール本数 & 台計 \\
\hline \multirow{2}{*}{ A } & $\mathrm{H} 521 \mathrm{~S}$ & $\mathrm{H} 1000$ & 6 & \multirow{2}{*}{8 肯 } & \multirow{2}{*}{$64 \div$} \\
\hline & $\mathrm{H} 521 \mathrm{~S}$ & H F 1000 & 2 & & \\
\hline$B$ & $\mathrm{H} 521 \mathrm{~S}$ & H1000 & 6 & 4 出 & $24 \frac{1}{13}$ \\
\hline
\end{tabular}

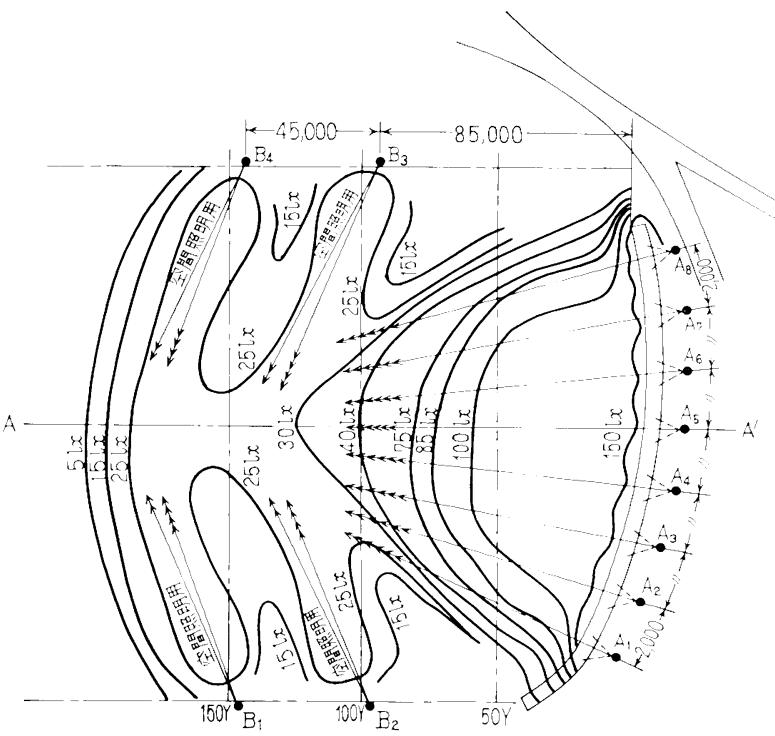

図 $6 \quad \mathbf{A}-\mathbf{A}^{\prime}$ 断面地上高さ $8 \mathbf{m}$ での 鉛直面照度図 (実測値) 